\title{
Rebellious attitude counseling effects of engineering students on English teaching
}

\author{
Chenxingwu \\ (Economics and Trade College of Foreign Languages of Wuhan Yangtze Business University, Wuhan Hubei, 430065) \\ chenxingwu666@163.com
}

\begin{abstract}
Due to weak foundation in English, thinking structural differences, and knowledge structure system, it is more difficult for engineering students to establish English thinking mode in the process of college English learning. It's easy for them to have rebellious attitude toward college English learning, which would directly affect the effect of college English teaching, thus eliminating engineering students' rebellious attitude in learning English becomes the problem that needs to be addressed. This paper takes engineering students in one Hubei university as the research object, adopts questionnaire survey method and data analysis method to study the effect of reverse psychology guidance on English teaching. Results show that a liberal arts student's English level is generally higher than that of engineering students. According to the study of engineering students, $46 \%$ have obvious negative mental performances, $39 \%$ have mild rebellious attitude, whose negative performance is not obvious, and the rest of the students have little rebellious attitude. Rebellious attitude has more significant negative effect on English teaching. Results show that psychological inversion can be overcome from cultivating engineering students' learning motivation, change the atmosphere of classroom teaching, improve teachers' quality, optimizing teaching mode, and develop diversified ways of teaching evaluation.
\end{abstract}

Keywords- Engineering students; Rebellious attitude; Genesis; English teaching

\section{INTRODUCTION}

Through many years of college English teaching practice, a widespread phenomenon has been found in colleges and universities that science and engineering students' English level and applying ability are worse than that of liberal arts students. Because of serious learning atmosphere, weak foundation in English, thinking structural differences, and knowledge structure system, engineering students often present a sharp learning enthusiasm decline with year goes by in learning process. After the relevant policies of national cancelling of English level tests and qualifications, engineering college students' English learning motivation decrease significantly in our country. Although English level still relates to graduates' employment capability and work ability evaluation, college English basic course in colleges and universities generally appear late arrival phenomenon, even absence. Bad class performance of engineering departments brings certain difficulties to college English classroom teaching, which directly leads to a significantly lower quality of college English teaching. [1${ }^{3]}$ That is more apparent in English engineering departments with poor grades. The comparison results of national College
English Test 4 and 6 average score of arts and engineering students in a university in Hubei province from 2005 to 2012 are shown in Figure 1.

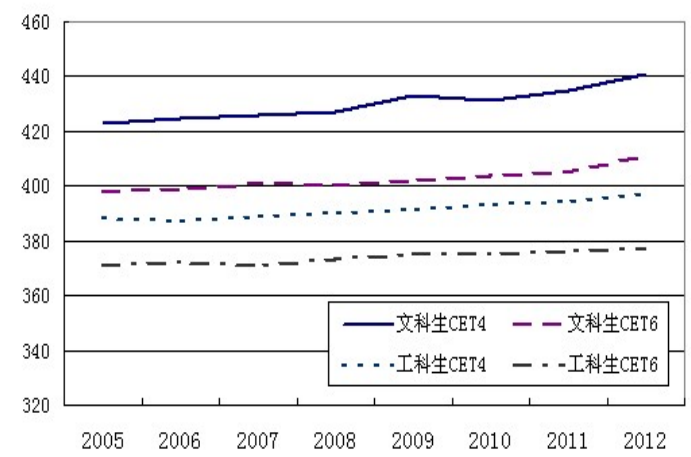

Figure 1. English score comparison results in one university from 2005 to 2012

As can be seen from Figure 1, the art students' College English Test 4 and 6 grades were higher than that of engineering students for many years in the university, and the average art student English level increases year by year, and the increase amplitude is higher than that of engineering students. And at the beginning of the reform, engineering students' English score in CET4 and 6 slightly backwards. There was an improvement after 2007, but the degree of increase is not obvious, which suggests that engineering students' English level is generally lower than that of liberal arts majors ${ }^{[4-5]}$. Currently the students accepted higher education often think college English education lacks practice, and oral competence hasn't got obvious practice. Teachers' teaching enthusiasm falls under the influence of rebellious attitudes of students which would hinder the development of college English teaching, and directly influence the effect of college English teaching, thus the influence of students' reverse psychology on college English teaching and how to correct students' reverse psychology have become a research focus in English teaching.

\section{THE MAIN REASONS FOR ENGINEERING STUDENTS REBELLIOUS ATTITUDES}

Education psychologists believe that rebellious attitude is due to students' emotional antipathy towards English learning. Rebellious attitude makes students feel uneasy mood, depression, and even opposite state. Rebellious attitude is common in engineering students' English learning, is more outstanding for students with lower scores. It is no doubt that rebellious attitude can influence greatly the effect of English teaching, therefore some scholars and education 
experts study how to improve college English teaching effect from repositioning teaching goal, optimize teaching mode, improve education evaluation ways, and cultivate high quality teachers' team, but the study achieved little in correcting engineering students' English negative mentality to change the present situation of English teaching. From the analysis of engineering students' English learning rebellious attitude causes, this paper analyzes the impact of engineering students' rebellious attitude on English teaching and improving measures. Based on the interviews with English teachers and college students, it can be found that there are three main reasons for engineering students' rebellious attitude in English learning process:

First of all, engineering students' dull personality traits influence English learning effect. Personality refers to different qualities expressing individual personality traits. Liberal arts students greatly differ from engineering students in personality traits those liberal arts students are relatively outgoing with agile thought, while engineering students are relatively dull with strict logic. Different group characteristics of arts and engineering have determined their usual study ways. Relatively outgoing liberal arts students' think agile; love to express themselves and pop questions, so they can quickly grasp the rhythm of learning in classroom learning. They actively participate in the activities of various kinds of oral English practice. Relatively ideal learning process usually makes them easy to have a sense of achievement, which further promotes learning. Engineering students are relatively introverted, and often seem reticent in language learning classroom. They don't want to express themselves, worry about being wrong and losing face. Because engineering students are introverted with poor English foundation. Encountering problems, they cannot ask promptly, which will often result in more and more big learning difficulties, and the problems are piling up. The learning effect is not ideal and can directly lead to students' lack of confidence in themselves and produce negative, resistance, depression, rejection in English learning. Therefore, the group quality of engineering students like boring, introverted, logical rigorous seriously influences English learning effect.

Second, the deviation of English learning motivation. The knowledge structure of engineering and liberal arts are greatly different, which has been evident in senior high school education in China. Engineering students accumulate negative anxiety in English learning in all logic thinking differences. After entering university, engineering students don't have a clear purpose of learning English which inspires negative and bored feeling. College English is a compulsory basic course of higher education, but it is still considered by most engineering students an edge discipline and unloved. Students do not get enough attention. Most engineering students pay more attention to the actual hands-on ability, and in order to lay a foundation to find an ideal job, they learn English to get CET4 and 6 certificates, that is to say, learning English is just to pass those tests, but for real mastering and using the world common language.

Finally, teacher quality and teaching methods have impact on English teaching. Current higher education enrollment expansion makes college English teaching task generally overweight. Most teachers need to bear heavy teaching tasks; they have too many classes weekly, and have to face more and more students. After the enrollment expansion, most colleges and universities move to remote University City in suburbs, which lead to teachers spending a lot of time and energy till the exhaustion of body and mind in the process of working. There is no clear division between teaching and scientific research which makes teachers do English teaching and heavy scientific research missions at the same time. This adds to the teachers' psychological pressure. Under the objective conditions, college English teaching quality would be affected to a certain degree, and the teacher won't have enough energy in teaching innovation and building teaching atmosphere.

\section{THE IMPACT RESEARCH OF ENGINEERING STUDENTS' REBELLIOUS ATTITUDE ON ENGLISH TEACHING}

\section{A. Data sources}

The study selects engineering students at a university in Hubei as research object. The research sent out 300 questionnaires, in which 274 questionnaires were collected, with $91.33 \%$ recovery rate. The effective questionnaires were 238 pieces, and the effective rate was $86.86 \%$. The descriptive statistics analysis results of the object study are as shown in Table 3-1.

TABLE 3-1 SAMPLE Descriptive StATISTICAL ANALysis TABLE

\begin{tabular}{|c|c|c|c|}
\hline $\begin{array}{c}\text { Statistical } \\
\text { variable }\end{array}$ & $\begin{array}{c}\text { classification } \\
\text { standards }\end{array}$ & number & proportion \\
\hline \multirow{2}{*}{ Gender } & male & 202 & $84.87 \%$ \\
\hline & female & 36 & $15.13 \%$ \\
\hline \multirow{2}{*}{ CET4 } & passed & 112 & $47.06 \%$ \\
\hline & failed & 126 & $52.94 \%$ \\
\hline \multirow{2}{*}{ CET6 } & passed & 46 & $19.33 \%$ \\
\hline & failed & 192 & $80.67 \%$ \\
\hline \multirow{3}{*}{ Grade } & 2010class & 65 & $27.31 \%$ \\
\hline & 2011class & 97 & $40.76 \%$ \\
\hline & 2012class & 76 & $31.93 \%$ \\
\hline
\end{tabular}

\section{B. Research variables}

This study selected the objects' College English Test band 4 scores y as the dependent variable to measure English teaching effect; the objects' gender D1 and grade D2 as virtual variables in improving the accuracy of the results; the research objects fond degree of learning English $\mathrm{x} 1$; the sense of identity for English teaching x2; English learning 
input degree $\mathrm{x} 3$ as the regression item interrelating the dependent variable; to study the effect of engineering students' rebellious attitude on English teaching.

\section{Research model}

This study uses multiple linear regression model in analyzing large outdoor sports activities' influence on the mass sports awareness and sports activities, and the model's specific formula is as follows:

$$
y_{i}=\varepsilon_{i}+\alpha_{i} x_{i}+\beta_{i} D_{i} \quad \text { (Formula 3.1) }
$$

In Formula (3.1), the dependent variable y is $\mathrm{N} \mathrm{x} 1 \mathrm{~d}$ column; regression item xi is the $\mathrm{N}$ x $3 \mathrm{~d}$ matrix, $\alpha_{i}$ is regression coefficient, $\mathrm{Di}$ is $\mathrm{N} \times 2 \mathrm{~d}$ matrix, ${ }_{i}$ is a virtual variable coefficient, ${ }^{\mathcal{E}_{i}}$ is random disturbance column vector. In order to investigate the accuracy of regression results of the model, the difference between the estimated value and actual value can be denoted by using residual error, and the specific calculation formula is as follows:

$$
\omega_{i}=\widehat{y}_{i}-y_{i}=\widehat{y}_{i}-\varepsilon_{i}-\alpha_{i} x_{i}-\beta_{i} D_{i} \text { (Formula 3.2) }
$$

The calculation formula of research model's regression coefficient according to residual error estimation is as follows:

$$
R S S=\sum_{i=1}^{N} \omega_{i}^{2}=\sum_{i=1}^{N}\left(\hat{y}_{i}-\varepsilon_{i}-\alpha_{i} x_{i}-\beta_{i} D_{i}\right)^{2}
$$

(Formula

3.3)

The relationship of variance and residual in random disturbance term is as follows:

$$
\begin{aligned}
& \sum \omega_{i}^{2}=\sigma^{2}(N-3) \text { (Formula 3.4) } \\
& \text { IV. EMPIRICAL FINDINGS }
\end{aligned}
$$

\section{EMPIRICAL FINDINGS}

\section{A. Descriptive analysis}

TABLE 4-1 THE DESCRIPTIVE RESULTS

\begin{tabular}{|l|l|l|l|}
\hline \multicolumn{3}{|l|}{ Dependent Variable: $\mathrm{Y}$} \\
\hline \multicolumn{3}{|l|}{ Included observations: 238} \\
\hline R-squared & 0.5126 & $\begin{array}{l}\text { Mean dependent } \\
\text { var }\end{array}$ & 3.1151 \\
\hline $\begin{array}{l}\text { Adjusted R- } \\
\text { squared }\end{array}$ & 9.1114 & S.D. dependent var & 3.1374 \\
\hline $\begin{array}{l}\text { S.E. } \\
\text { regression }\end{array}$ & 3.7369 & $\begin{array}{l}\text { Akaike } \\
\text { criterion }\end{array}$ & 7.6731 \\
\hline $\begin{array}{l}\text { Sum squared } \\
\text { resid }\end{array}$ & 31.3124 & Schwarz criterion & 6.7616 \\
\hline $\begin{array}{l}\text { Log likelihood } \\
\text { F-statistic }\end{array}$ & -79.0113 & $\begin{array}{l}\text { Hannan-Quinn } \\
\text { criter. }\end{array}$ & 7.8713 \\
\hline
\end{tabular}

As can be seen from Table 4-1, the value of model R2 is 0.5126 , which shows that in the process of linear regression analysis, the explaining part of the return item for the dependent variable is $51.26 \%$. The explaining part accounts fair, which explains the selection of independent variables is relatively appropriate, and the return results of the research have a certain practical reference value. It can be seen from combination model of AIC and SC test values that the model this institute applying passed the validity check of Akaike information criterion and the Schwarz information criterion, so the model structure this study uses is suitable for the analysis of sample data. Dependent variable y's $P$ value is 0.0113 , which means the estimated value of the dependent variable in linear regression analysis is credible above 5\% level of significance. The estimated value of dependent variable of the study's model is very close to the actual value, and the research results by regression analysis are of high reliability.

\begin{tabular}{|c|c|c|c|c|}
\hline \multicolumn{5}{|c|}{ Dependent Variable: Y } \\
\hline \multicolumn{5}{|c|}{ Sample: 1238} \\
\hline \multicolumn{5}{|c|}{ Included observations: 238} \\
\hline Variable & Coefficient & Std. Error & t-Statistic & Prob. \\
\hline $\mathrm{C}$ & 9.2142 & 1.086 & 6.73 & 0.0316 \\
\hline D1 & -3.3216 & 1.5226 & -1.3950 & 0.0101 \\
\hline D2 & -1.2406 & 0.5932 & -0.3817 & 0.0446 \\
\hline $\mathrm{X} 1$ & 7.1389 & 1.1513 & 3.6358 & 0.0414 \\
\hline $\mathrm{X} 2$ & 6.2233 & 0.7325 & 0.5525 & 0.0157 \\
\hline $\mathrm{X} 3$ & 1.9167 & 0.5156 & 1.9423 & 0.3123 \\
\hline
\end{tabular}

\section{B. Empirical result analysis}

TABLE 4-2 ENGINEERING STUDENTS' NEGATIVE PSYCHOLOGICAL IMPACT ON ENGLISH TEACHING

As can be seen from Table 4-2, virtual variable D1 and $\mathrm{D} 2$, independent variable $\mathrm{x} 1$ and $\mathrm{x} 2$ have passed the significance test of 5\% level. The regression results show that the overall study has higher reliability. Regression coefficient is positive, and the greater the coefficient of regression, the greater is the impact of regression variables on the dependent variables. Regression coefficient is negative, and the smaller the coefficient of regression, the greater the negative impact of regression variables on the dependent variables. Seen from the results, the study objects' gender, age, fond degree in English learning, and students' identity degree of English teaching model can significantly affect English teaching effect. From the regression results of the study, it can be seen that in a serious imbalance between male to female ratio in engineering colleges and universities, the boys' English average score is generally lower than that of girls. The higher the grade of the students, the lower is their average English grade. In addition, the higher of 
engineering student interest in learning English, the higher score in English. The higher the recognition of English teaching mode, the better effect is in English teaching. It can be seen from the results of the study that college English teaching can adopt the following measures to correct the students' rebellious attitude:

First, improve English learning needs hierarchy, and stimulate students' learning motivation. Need is the potential power of people activity. For engineering students, praises and obtaining ideal job opportunities are the main motivations to improve the students' hierarchy of needs and arouse their potential power, which has a lot of inspiration for college English teaching. Teachers should let students deeply aware of the practical usage of English and their insufficient language ability. If do not rely on classroom learning, they will not be able to reach more systematic, more in-depth learning can contribute to the students' selfreflection and inspire them to learn.

Second, encourage students and enhance learning confidence. University enrollment expansion lessens teachers' energy devoted to each student, but teacher can give more hints and encourage the student. If some students get the teacher's suggestion and encouragement and think they are successful, then the students are likely to have more confidence to strengthen learning English, and get better English teaching effect. Place good hope and good encouragement upon students, and students' learning attitude will shift gradually. From negative to positive, this will improve English teaching effect.

The third is to adjust teaching methods to stimulate students' interest. To change students' passive resistance in college English learning attitude, the key is that teachers adjust teaching method to stimulate students' interest in learning English. The current study results show that the establishing class of students-centered, students as the main body of the classroom can stimulate students' interest in learning, but the fact is that teacher is still dominant in the classroom and takes up most of class time. The interpretation of teachers gives students less time, or students' autonomous learning without scientific guidance which makes it less effective. For engineering students with strong hands-on ability, English teachers can design more of the computer aided teaching, through combining the content of teaching and professional content, design courseware with rich content and new form to inspire students' innovative thinking ability in English learning, enhance the enthusiasm of students learning English, and improve English teaching effect.

\section{CONCLUSION}

It is a common problem for engineering students have rebellious attitude in college English learning. Through the empirical research, provide a feasible and effective teaching advice for college English teaching to avoid the ignoring phenomenon of schools and teachers of students' rebellious attitude. In the teaching process, teachers should often reflect on the teaching method, if it is used correctly, how to make college English teaching receive good effect, and how to effectively help the students improve the level of the English language.

\section{REFERENCES}

[1] Hauser M D,Chomsky N,Fitch W T.The faculty of language: What is it, who has it, and how did it evolve. Science . 2002.

[2] Littlewood W.Communicative Language Teaching: An Introduction. . 1981.

[3] Lantolf JP.Introducing sociolcultural theory. Sociocultural Theory and Second Language Learning . 2000.

[4] FANG Lu. Application of the Internet of Things Technology in the Museum Service[J]. Bulletin of Science and Technolog, 2013,3(28):166-168.

[5] PAN Jun-yang. Signal Detection in Strong Chaotic Interference Based on RBF Neural Network[J]. Computer Simulation, 2010.5:136139. 